Светозар Бошков

Универзитет у Новом Саду

Филозофски факултет

Одсек за историју

svetozarboskov@hotmail.com
Оригинални научни рад

примљено: 1. јун 2011

прихваћено: 1. октобар 2011

\title{
ИСТОРИЈА КАО НАУКА У УЏБЕНИЦИМА СТОЈАНА БОШКОВИЋА*
}

Сажетак: Циљ овог рада је да на основу података у уџбеницима историје које је написао Стојан Бошковић представимо његове погледе на циљеве и задатке историје у васпитно-образовном процесу, као и да представимо унапређење наставе историје и утицај који је имала на образовање српске омладине у XIX веку.

Кључне речи: Стојан Бошковић, историја, уџбеник, XIX век.

О историји као науци написано је много студија. Историчари су од античких времена па до данашњих дана тражили одговоре о судбини људи, друштвеним процесима у којима су учествовали и посебно о државним уређењима и системима у којима су људи живели с циљем да спознају суштину људског деловања и опстанка. Наш истакнути историчар и академик Чедомир Попов је написао да је увек постојала та тежња човека ка великим мисаоним, религиозним, идеолошким или философским системима, помоћу којих ће спознати и сагледати целину света, његову природну и социјалну суштину и своје место у њему. ${ }^{1}$ Српска историографија се током XIX века развијала на специфичан начин, у тешким друштвеним и политичким околностима тежећи да активно прати европске и светске трендове у проучавању историје. Стојан Бошковић је био један од оних историчара који су на специфичан начин, преко образовног процеса, утицали на развој историје као науке код Срба у ХIX веку.

Српске гимназије у XIX веку биле су организоване по принципу класичне наставе, а прошлост старих Грка и Римљана чинила је основу образовања српских ђака. Античка прошлост није се слушала само на предмету историја, него и на

\footnotetext{
* Рад је настао као фазни резултат републичког пројекта број 177002 под називом Војвођански простор $у$ контексту европске историје.

${ }^{1}$ Чедомир Попов, O историји и историчарима, Сремски Карловци - Нови Сад 1999, 16.
} 
књижевности, философији, географији, реторици и многим другим предметима, а један од циљева и задатака историје био је да образује будуће генерације српских интелектуалаца на античким принципима. У то време основу наставе историје чинили су уџбеници историје, а један од аутора тих уџбеника био је и Стојан Бошковић. Он је написао неколико уџбеника историје, а овде ће бити представљена два. Први се појавио 1866. године под насловом Историја света за народ и школу, књ. 1, Историја старог века, а други 1883. године под насловом Историја света за више разреде средњих школа са сликама, део 1, Стари век, св. 1. У оба уџбеника забележене су новине које нису биле карактеристичне за уџбенике у то време, а посебно у погледу представљање историје као науке.

Његов први уџбеник из 1866. године штампала је Државна штампарија у Београду и састоји се од 389 страница и једне историјске карте која је дата као прилог на самом крају. На овој карти је приказана Грчка у време Пелопонеског рата, Исток у време Александра Великог и Запад у време Римљана. Основна карактеристика уџбеника историје на српском језику који су се појавили пре овог уџбеника С. Бошковића била је у томе да се на почетку расправља о постанку света, при чему доминирају одломци из Старог завета у чијој основи је прича о Адаму и Еви, а затим се излаже историја старих народа према географској распрострањености. Међутим, у овом уџбенику дошло је до неколико крупних промена, а најважнија је да је на почетку излагања историја представљена као наука. Неколико уводних поглавља обухвата објашњење шта проучава историја, како се развија историја, које су помоћне историјске науке, шта су то историјски извори и како се дели историја света.

У уводном делу уџбеника Бошковић објашњава чиме се бави историја и који су њени задаци. Он каже: ,а сви (народи) заједно мање више раде или бар мисле да раде за боље; онда ћемо се уверити, да се је живот људима и народима непрекидно мењао, на боље или на горе; па морамо да се запитамо, како ли је било пре нас, пре наших очева и дедова, пре стотине и хиљаде година, какви су у то и то доба били људи и народи, и како ли је свет дошао до свакога стања како сада видимо око нас. Тако истражујемо узроке и послетке тима изменама, том развитку живота човечанског, те дознајемо зашто је било и одкуда је дошло све оно што замаша у судбину народа. Кад то чинимо, па још увиђамо зла и погрешке пређашњих векова, а примамо к срцу добра дела и угледамо се на лепе примере старијих колена; онда не радимо друго већ се бавимо науком над свима наукама, учимо историју, повестницу рода људскога. И тако историја је прича о истинитим а важним догађајима, са којих се изменуо облик народнога и општега човечанског живота“. ${ }^{2}$ Дакле, Бошковић у први план истиче истину и причу о важним догађајима из прошлости живота старих људи као основни предмет проучавања историје. У том процесу важно је представити и добре и лоше примере из живота старих људи и тражити узроке и последице тих примера, јер они показују како се развијало човечанство. Истина, колико год она била добра или лоша, представља основ историјског знања, а ученици на основу примера који су представљени у уџбенику

\footnotetext{
${ }^{2}$ Стојан Бошковић, Историја света: за народ и школу. књ. 1, Историја старог века, Београд 1866, 2.
} 
усвајају те историјске истине и уче како да разликују добро од лошег и да у сличним ситуацијама реагују сходно моралним начелима, која треба да представљају покретаче историјског процеса.

О задацима историје Бошковић каже: „А особито њој је задатак да објасни оне знамените покрете и промене, што за векове пресуђују судбу народима и крче пут развитку људског рода; а то су или мирне поправке (реформе) што проистичу из опште свести а извршују се заједничким договором између народа и поглавица или су насилни потреси и буне (револуције), кад народи сами понајвише с оружјем у руци потраже правду и хоће да се ослободе насилничког јарма. Тако је историја огледало прошлости, она је видело садашњости, она нам показује пут будућности“. ${ }^{3}$ Јасно је да задатак историје није нимало лак. Развој људског рода, како каже Бошковић, условљен је друштвеним променама и околностима у којима су се те оне одиграле. Да би се те промене правилно сагледале, историчар мора, пре свега, истинито да представи прошле догађаје, како би они користили будућим генерацијама. С обзиром да се друштвене околности стално мењају, задатак историје је да истинито представи и тумачи прошле догађаје с циљем да се што лакше објасне и сагледају нове друштвене промене. У том процесу важан задатак имају и помоћне историјске науке.

У уџбенику су представљене две помоћне историјске науке: земљопис или географија и хронологија. По Бошковићу, једна од најважнијих помоћних историјских наука је земљопис или географија. Он каже да земљопис представља основ историје и његов задатак је да нам покаже место, односно где се догодило све што је важно за историју. Историчар поготово мора да води рачуна о станишту народа где живе, односно о природи и околини у којој живе. Током излагања поставља питање да ли би сви народи који су нам познати у историји заиста допринели развоју човечанства да су се којим случајем затекли на другом месту. ${ }^{4}$ На ово питање је и данас веома тешко одговорити. Оно што је извесно је да су антички народи, које ми данас познајемо, славу стекли и због простора који су насељавали и где су развијали своје друштво, и управо су тешки услови живота и борба за преживљавање одиграли важну улогу у процесу промене и развоја друштва код тих народа. Принцип географске поделе приликом представљања одређених народа примењиван је и у овом уџбенику, као и у претходним уџбеницима историје на српском језику. По правилу су се увек прво представљали народи старог Истока, затим Африке и на крају Европе, али никад до тада земљопис (географија) није представљен као помоћна историјска наука.

Друга важна помоћна историјска наука по Бошковићу је хронологија. Њен задатак је да одреди време када се неки догађај одиграо. Овај задатак није лак. Основни проблем представља то што нису сви народи исто рачунали време, нити је година, како наводи Бошковић, код свих исто трајала, нити је у исто време почињала. Као пример он представља разлику у бројању година, односно почетку рачунања времена. Тако Грци рачунају време од прве Олимпијаде 776. године пре

\footnotetext{
${ }^{3}$ С. Бошковић, Историја света 1866, 3.

${ }^{4}$ Исто, 5-6.
} 
нове ере, Римљани од оснивања града 753. године пре нове ере, а хришћани од рођења Христа, с тим да и ту постоји разлика од 12 дана у зависности од тога да ли је у питању западни или источни календар. Посебно је важна упоредна хронологија. За неке народе, иако се спомињу у историјским изворима, немамо тачне податке о томе када се шта догодило, али упоредном хронологијом са постојећим догађајима можемо приближно одредити време. ${ }^{5}$ Бошковић је први српски аутор који се детаљно бавио питањем и улогом хронологије у историјском процесу.

Бошковић затим даје преглед историјских извора. Он каже да „можемо говорити само о историји оних народа, од којих је остало буди каквих споменика. А народ који је прошао или још живи (нпр. дивљачки), па од прошлости његове ништа важно није заостало потомству, - такав народ не може ни да изађе на поље историје. Многи народи преминули су, затрли се или се прелили у друге народе, па од њих нема сада ни гласа ни трага.“6 Оно што је важно за историју као науку код Бошковића је да историјске изворе дели усмене, неме (мртве) и писмене. У усмене изворе спадају приповетке, казивања и народна предања (традиције) с оца на сина и народне песме. Он каже да са овим изворима морамо бити крајње опрезни, јер они нису поуздани. У неме (мртве) изворе спадају слике и грбови (хералдика), зграде и зидови, скулптуре, стубови, развалине од градова, храмови и куће, посуђе, оруђе и оружје. Наука која се бави овим изворима је археологија.

У писаним изворима постоји разлика и дели их у две групе. У првој су писани извори у које спадају натписи (епиграфика), новац (нумизматика), медаље и печати (сфрагистика), а у другој групи су јавна писма, државни уговори, наредбе владара и укази (повеље), уговори, споразуми и извештаји, дипломе, летописи (анали) и хронике. Али најважнији од свих извора су, по Бошковићу, историјске књиге. Ипак, веома је важно што Бошковић на крају пописа свих извора каже „да сви извори тек онда вреде, кад се историјском критиком претресу, пречисте и оцене“, 7 јер је то процес којим се долази до историјске истине. Међутим, иако напомиње да су историјске књиге најважнији од свих извора, он само у фусноти наводи списак најважнијих писаца старог века за периоде које је представио у књизи па је тако за Јевреје извор Библија, за Грке Херодот, Тукидид, Ксенофонт, Полибије, Дионисије из Халикарнаса, Диодор са Сицилије и Плутарх, а за Римљане Салустије, Тит Ливије, Корнелије Непот и Такит. ${ }^{8}$

Иако их у претходном делу о помоћним историјским наукама није издвојио као посебне науке, Бошковић објашњавајући који све историјски извори постоје и како су подељени практично говори о још неколико помоћних историјских дисциплина. На првом месту то је археологија која се бави проучавањем, како Бошковић истиче, „немих (мртвих) извора“, а затим набраја још и епиграфику, сфрагистику и нумизматику које спомиње приликом описа писаних историјских извора.

\footnotetext{
${ }^{5}$ С. Бошковић, Историја света 1866, 7-11.

${ }^{6}$ Исто, 11.

${ }^{7}$ Исто, $12-13$.

${ }^{8}$ Исто, 13 .
} 
Према мишљењу С. Бошковића последњи важан фактор за историју као науку је периодизација. У уџбенику из 1866. године Бошковић историју дели на два периода - стари, који још назива и незнабожачка периода, и нови, који назива периода нова. Стари период обухвата време од стварања света до појаве Христа Спаситеља и у ту велику епоху укључује и пропаст Римског царства, а трајање ове епохе Бошковић ограничава на 3000 година. Други период, периода нова, период је хришћанства и траје све до данашњих дана. У оквиру овог новог периода Бошковић издваја још два периода од којих први рачуна од појаве Христа до проналаска Америке и реформације, а други период траје од тог времена до данас и назива га нови век. У периодизацији коју нам даје Бошковић примећујемо неколико недоследности. Пре свега, приликом одвајања незнабожачког периода и периоде нове као границу користи рођење Христово. Међутим, управо ту је и проблем ове периодизације, јер је Римско царство трајало и после Христовог рођења и то још пет векова. Интересантан је и назив првог периода, незнабожачки период, јер по њему испада да пре појаве Христа народи и друштва која су организована нису познавали веровање у богове и негира постојање самих божанстава, што знамо да није тачно. Пре бисмо могли да истакнемо да је Бошковић овде хтео да одвоји хришћанство од претходних религија, али то није урадио на адекватан начин. Чак и наставак текста овог уџбеника говори сасвим супротно називу овог периода, јер Бошковић веома често говори о веровањима старих народа током излагања њихове историје.

Ако је први уџбеник представљао пионирски рад у представљању историје као науке, онда је други уџбеник Историја света за више разреде средюих школа из 1883. године показао једну сасвим нову Бошковићеву тежњу, којом је отишао корак даље и покушао да објасни потребу учења историје у школама. Данас нам је сачувана само прва свеска, која носи наслов Стари век, али се бави преисторијским добом. У уводу овог уџбеника С. Бошковић је писао о стању школа у најразвијенијим европским земљама: “У другим земљама, где је настава и литература школска много одмакла, предаје се историја у већем пространству. Тако у Француској по најновијем наставном плану и с програмом од 1880 . године сама историја источних народа у једној књизи од 400 страна ситнијег текста долази, у једном разреду, историја Грка опет засебно у једној, а Римљана у другој години (по Француском уређењу VI, V и IV разред, а то одговара нашем III, IV и V разреду). У трећем разреду (нашем шестом) историја Јевропе и Француске до краја 16. века у једној књизи од 700 страна ситнијег слога. Тако је народна и општа, средња и новија историја распоређена поступно у нижим и вишим разредима. У Немачкој и Инглеској свраћа се такође велика пажња и даје довољно простора овом предмету. Но озбиљни научници с гледишта педагогије и хигијене саветују, да се ученици не товаре сувише часовима. А за историју нарочито мисли се, да вредан и добро спремљен професор може и с мање часова да савлада доста грађе, па и ученицима да омили предмет толико да га сматрају као прилику за корисну поуку, и средство за лепу духовну забаву.“9 Иако је и сам писао уџбенике, С. Бошковић посебно истиче

\footnotetext{
${ }^{9}$ Стојан Бошковић, Историја света: за више разреде средюих школа. Део I: Стари век. Св. 1, Београд 1883, X.
} 
важну улогу наставника у наставном процесу, без обзира на литературу и уџбенике које поседује, али и опомиње на потребу да су настави историје у српским школама потребни нови уџбеници на српском језику. ${ }^{10}$ Овде бисмо помислили да се ради о једном класичном уџбенику, међутим није тако. У овој књизи Бошковић се више бави питањима потребе проучавања историје и обима градива које треба да има историја у средњим школама. Затим лекције су потпуно различите од онога што се очекује од средњошколског уџбеника. На пример, у овом уџбенику постоје лекције које се баве стаништима првих људских заједница, њиховој привреди, облачењу или трговини, али у таквом обиму да би се пре могло рећи да се ради о једном научном историографском делу са критичким освртом на досадашња проучавања, него о средњошколском уџбенику. Бошковић на више места посебно истиче да историја увек мора да буде подложна критици, а подаци који се износе морају да буду у складу са истином.

С обзиром на данашњи развој историографије веома је тешко говорити о историји као науци у српским уџбеницима историје који су изашли у XIX веку. Међутим, ти уџбеници представљају пионирске подухвате у нашој историографији и поред свих својих специфичности и мана представљају важне прекретнице на путу развоја историје као науке код Срба током XIX века, а Стојан Бошковић је само један од аутора који је дао свој допринос том развоју.

\section{Извори и литература:}

Бошков, Светозар, Уцбеници античке историје у српским школама у 19. веку, Зборник радова са скупа, Антика и савремени свет, Београд 2007, 21-34.

Бошковић, Стојан, Историја света: за народ и школу. Књига 1, Историја старог века, Београд 1866.

Бошковић, Стојан, Историја света: за више разреде средњих школа. Део I: Стари век. Св. 1, Београд 1883.

Попов, Чедомир, О историји и историчарима, Сремски Карловци - Нови Сад 1999.

\footnotetext{
${ }^{10}$ Светозар Бошков, Уцбеници античке историје у српским школама у 19. веку, Зборник радова: Антика и савремени свет, Београд 2007, 26.
} 
SVETOZAR BOŠKOV

\title{
HISTORY AS A SCIENCE IN TEXTBOOKS OF STOJAN BOŠKOVIĆ
}

\begin{abstract}
Summary
Based on data in the history textbook written by Stojan Bošković in this article are presented his views on the goals and tasks of history in educational process and influence that had on the education of the Serbs in $19^{\text {th }}$ century.
\end{abstract}

Keywords: Stojan Bošković, history, textbook, 19th century. 